\title{
ANALYSIS OF SYNTACTIC THEORIES OF ASSOCIATION IN LINGUISTICS
}

\author{
Nodira Abdirasul Qizi Makhmadmurodova
}

Lecturer Department Of Uzbek Language And Literature Karshi Institute Of Engineering And Economics

\section{ABSTRACT}

This article discusses the syntactic theories of compounding in world linguistics, examines the views of linguists on compounding, and points out the differences and similarities in these studies. In particular, the theoretical and practical work of Russian, German, Turkish and English linguists on linguistics has been studied and their views have been highlighted. In particular, it was noted that until now, the problem of vocabulary has been one of the most important issues on the agenda of scientific research

KEYWORDS:- Language, compound, compound term, phrase, free compound, fixed compound, Russian linguistics, German linguistics, English linguistics, Turkish linguistics, traditional linguistics, systemstructural linguisticsv.

\section{INTRODUCTION}

The language is constantly developing in close connection with the history of the people, with the events taking place in society. As the historical stages of the language have left an indelible mark on the language, all levels of the language are constantly changing, which is especially noticeable at the lexical level of the language. At the syntactic level of the language, however, this happens much more slowly. Identifying these changes, researching them, and finding solutions to problems identified in language have been a major theme in the research work of a number of scholars. To study the process of language change in a diachronic way, to compare certain periods in the history of language with the current situation, to reveal the factors that led to this evolutionary development, one of the most important tasks of linguistics is to identify the smallest structural changes in it, as well as large-scale innovations and radical changes, to determine their laws. By performing these tasks, we can better understand the evolutionary development of language, and have a conscious and cultural approach to language.

\section{Material AND Methods}

It is known that changes in the language occurred slowly at the morphological and syntactic stages. Because the grammatical stage is conservative, it is not influenced by the impressions of the time and period, and changes 
CURRENT RESEARCH JOURNAL OF PHILOLOGICAL SCIENCES 2(5): 13-17,

May 2021 DOI: https://doi.org/10.37547/philological-crjps-02-05-04

ISSN 2767-3758

(C)2021 Master Journals

\section{Crossref do) 81 Google}

Accepted23 $3^{\text {th }}$ May, 2021 \& Published 28 $8^{\text {th }}$ May, 2021

in these areas take place over the centuries. However, these changes have been studied. In particular, phrases as a syntactic phenomenon in the form-structure of traditional linguistics in the works of Russian linguists such as V.V. Vinogradov, N.N. Prokopovich, O.S. Akhmanova, F.P. Filin, N.Y. Shvedova, as well as V.N. Sukhotin, N.I. Flicheva, Scholars such as V.Yung, O.Behagel, J.Erbin in German linguistics, Turkic studies NKDmitriyev, S.E.Malov, E.D.Polivanov, A.N.Kononov, N.A.Baskakov, A.M.Shcherbak, M.Balakayev, M.Z.Zakiyev, N.G. in the researches of Turkish linguists such as T.Banguoglu, M.Ergin, L.Karakhan, Uzbek linguists G.A. Abdurahmonov, F.Abdullayev, Sh.Shukurov, Q.Karimov, H.Nazarova, A.N. Nurmonov, N.Mahmudov, A.Koklyanova, A.Berdialiyev, H.Kholiyorov, V. V. Reshetov, T .Rustamov, A.Safayev, A. Gulomov, M. A. Askarova, M.Sharipov, T.Khojayev. Issues of word development are studied in general in the books of F. A. Abdullayeva, F. I. Ibrahimova, G. Karimov, A. Ahmedov, S. Goyibov.

The concept of phrase in Russian linguistics was founded in 1757 by M. V. Lomonosov. In "Russian Grammar", the scholar argued that in order for an idea to be expressed, independent words must interact, and therefore the main task of syntax must be to study the interrelationships of word groups.

In recent years, interest in the basic communicative unit of speech has increased, leading to a decline in vocabulary research. However, the issue of wording has not escaped the attention of scholars. In particular, F. F. Fortunatov pays special attention to the issue of word combinations in his works, and considers that the sentence is complete and the word combinations are incomplete. F. F. Fortunatov divides phrases into grammatical and nongrammatical phrases. Grammatical phrases include conjunctions connected by certain formal grammatical means (poultry is flying, good weather), nogrammatical conjunctions without conjunctions (Poet Pushkin) [12.182].

A.M. Peshkovsky, a follower of F. F. Fortunatov, states that syntax is a branch of grammar that is the study of word forms. Such a definition of syntax leads to the formation of two syntactic constructions - a sentence and a phrase. A. M. Peshkovsky interprets all types of sentences (except words) as phrases. Such an approach to a phrase leads to a discrepancy between the phrase and the sentence. A. A. Shakhmatov took a completely new approach to the phrase. According to him, a phrase is present in the sentence structure and studies the relationship of the secondary parts to the main parts and their relationship to each other. Thus, the theory of words is completely subordinated to the theory of speech. His syntactic teachings focus on vocabulary, which accounts for one-third of the book.

In N. N. Prokopovich's research, the theory of word formation is also based on the teachings of VV Vinogradov. However, N. Prokopovich also considers the existence of a type of phrases based on the method of connection, and correctly shows that they are open structural, and compounds based on the method of following are closed structural syntactic devices.

The German scientist Y. Rees has a special place in the study of the nature of phrases. He understands a phrase as a lower syntactic unit, and a higher syntactic unit is very different from a sentence. In the teachings of Y. Reese, a phrase is studied in comparison with an independent word [13].

0. Bexagel is also involved in the study of word combinations in German linguistics. According to him, the concept of "Wortgruppen" includes both subordinate clauses and equivalent clauses, and even syntactic structures consisting of a combination of independent and independent words. Common views on Behagel's views have 
CURRENT RESEARCH JOURNAL OF PHILOLOGICAL SCIENCES 2(5): 13-17,

May 2021 DOI: https://doi.org/10.37547/philological-crjps-02-05-04

ISSN 2767-3758

(C)2021 Master Journals

\section{Crossref do) 81 Google}

Accepted23 $3^{\text {th }}$ May, 2021 \& Published 28 $8^{\text {th }}$ May, 2021

been expressed in German linguistics by such scholars as R. Blumel, Y. Erbin, and W. Yung. They even suggested that the connection between the preposition and the noun formed a phrase [14.33-34].

In English linguistics, the main objects of syntax are words and phrases. Some English scholars have divided syntactic relations into adjunct + words and dominant words or headwords. They studied the syntactic connection or relationship between one-way and two-way communication.

\section{Results AND DISCUSSION}

It is well known that the question of the syntactic relationship of words has long been of interest to linguists. As a result, there has been a great deal of research in linguistics on this issue. However, it should be noted that this issue, unlike other Indo-European languages, is based on Russian language materials. As early as the 18th century, $\mathrm{M}$. V. Lomonosov was interested in the nature of word combinations in this work. Although there was no such thing as a "phrase" at the time, one section of the syntax focused on the ways in which words were combined and the structural forms of phrases. His idea was later gradually developed by linguists such as A.Kh. Vostokov, F. F. Fortunatov, A. M. Peshkovsky. After M. V. Lomonosov, A. H. Vostokov dealt with the problem of wording. In his grammar, too, part of the syntax is called "about the addition of words", and the phrase is interpreted as a combination of words. A. M. Peshkovsky also developed M. V. Lomonosov's views on this subject, as evidenced by the following statement: "A phrase is a combination of two or more words in a speech according to the content" [15].

F. F. Fortunatov's syntactic views played an important role in the development of Russian grammar. His views are, to a certain extent, fundamental to the problem of vocabulary.
Over the last 30 years, the study of word syntax in Russian linguistics has reached a new stage. Scholars such as V.V. Vinogradov, V. P. Sukhotin, and N. N. Prokopovich played an important role in the development of its theoretical aspects. In their work, the doctrine of word syntax is defined as a separate object, along with the doctrine of speech. V. Vinogradov's teaching states that a phrase is made up of at least two independent words and that the sentence is the building block. The doctrine emphasizes that a phrase is a non-predicative syntactic device: "A phrase cannot have a message tone on its own. The categories that own it, the cut, and the relationship between them and the rest of the sentence are alien" [16].

Russian linguists V. P. Sukhotin and A. N. Gvozdev argue that there are non-predicative and predicative forms in the following conjunctions. In addition, A.N. Gvozdev's research suggests that a phrase should always be studied as it is given in the sentence, and that it can be examined separately from the sentence only for modeling.

Vocabulary is one of the most studied areas in German linguistics. German linguists study the combination of an article and a horse as a combination of words, and study the combination of words into three types. From this we can see that the existing views on the issue of vocabulary in German linguistics are in some respects similar to the views on the issue of vocabulary in Turkish linguistics.

In English linguistics, devices connected by equal communication are also included in the compound, which clearly shows the difference between Uzbek linguistics. Accumulative communication refers to the addition of phrases to other elements. For example, (towrite) his friend a letter or a letter to his friend are connected to each other by means of two complementary accumulative connections. A 
CURRENT RESEARCH JOURNAL OF PHILOLOGICAL SCIENCES 2(5): 13-17,

May 2021 DOI: https://doi.org/10.37547/philological-crjps-02-05-04

ISSN 2767-3758

(C)2021 Master Journals

Crossref doi 81 Google

Accepted23 ${ }^{\text {th }}$ May, 2021 \& Published 28 $8^{\text {th }}$ May, 2021

similar opinion is observed in the works of L. S. Barkhudarov and E. I. Shutova.

\section{Conclusion}

In general, we see that the topic of vocabulary is very problematic in world linguistics. Therefore, not only in Uzbek and Turkish linguistics, but also in general linguistics, there are still many explanatory issues in the study of the nature of phrases.

It is clear from this information that although much work has been done on the wording, the issues covered in this topic have not been made clear. For example, scientists have different views on the nature of the phrase. They are as follows:

1. There are two opposing views on the meaning of a phrase and its origin. The first is the traditional syntactic branch of linguistics, which is mainly associated with the names of F. F. Fortunatov and his followers A. M. Peshkovsky, A. A. Shakhmatov. According to them, a phrase exists only in its structure and cannot be outside the sentence. The opinion of Academician V.V. Vinogradov is the complete opposite. According to him, a compound has a nominative function like a word, and it is an expanded form of the word. It can be in or out of a sentence [17].

Some scholars cite nominative headlines in newspapers as examples of phrases that may exist outside the sentence. This is not a manifestation of its particular use, but a peculiar feature of newspaper speech, the content of which is learned from those contexts, and it is impossible to distinguish them from those contexts at all.

2. What phrases can be considered phrases? There is no consensus among scientists on this issue either. Some scholars believe that the object of syntax is a phrase, and include a sentence in the phrase. Another group of scholars approaches this approach in terms of the syntactic function of parts of speech, and also considers predicative conjunctions as word combinations. They distinguish between descriptive, complementary, and non-predicative compounds. The third group of scholars does not consider predicative conjunctions to be word combinations. They include only non-predicate conjunctions that are related to each other.

3. It's a matter of phrase structure. Some scholars consider the combination of independent and auxiliary words to be a compound word, while others say that the grammatical connection of two independent words forms a compound word. Acad. V. V. Vinogradov, on the other hand, had the ability to express a phrase as an object, action, etc.: representing a single complex meaning: clarifies that it is a combination of two independent words that are syntactically formed and semantically integrated [18.106]. Nowadays, linguists acknowledge that the fact that phrases consist of two independent words is the main criterion for the formal formation of phrases.

\section{REFERENCES}

1. Vinogradov V.V. Questions of the study of the phrase, VYa. 1950 №3

2. Fortunatov F.F. Selected Labor. Slavic language studies. Tashkent:, Moscow:,1956, P.182.

3. Mustafa Ch. Syntactic derivations of phrases in modern Uzbek and Turkish languages. Candidate of Philological Sciences dis. avtoref. - Tashkent, 2002.

4. Mahmudova N. On subordination and equivalent syntagmas // Sahibqiron stars. 2017, №2. - P. 33-34

5. Gulyamov A., Askarova M. Modern Uzbek 
CURRENT RESEARCH JOURNAL OF PHILOLOGICAL SCIENCES 2(5): 13-17,

May 2021 DOI: https://doi.org/10.37547/philological-crjps-02-05-04

ISSN 2767-3758

(C)2021 Master Journals

Crossref do) 80 Google

Accepted23 ${ }^{\text {th }}$ May, 2021 \& Published 28 $8^{\text {th }}$ May, 2021

literary language. - Tashkent: Teacher,1987. - P. 255.

6. Sharipov M.K. The problem of syntax of words in Uzbek language. - Tashkent, "Science".1978, P.88.

7. Modern Uzbek language. Syntax. Tashkent:, “Classic word”, 2013.

8. Uzbek grammar. Part I. - Tashkent:, 1978.

9. Mahmudov N., Nurmonov A. Theoretical grammar of the Uzbek language. Tashkent: Teacher, 1995. - P. 230.

10. Issues of development of Uzbek phrases in the XX century. Jabborov R. Mag.diss. Nukus:, 2014.

11. Nurmonov A. History of Uzbek linguistics Tashkent:, “Uzbekistan”.2002.

12. Fortunatov F.F. Selected Labor. Slavic language studies. Moscow:, 1956, P. 182.

13. Mustafa Ch. Syntactic derivations of phrases in modern Uzbek and Turkish languages. Candidate of Philological Sciences dis. avtoref. - Tashkent, 2002.

14. Mahmudova N. On subordination and equivalent syntagmas // Sahibqiron yulduzi. 2017, №2. - P. 33-34

15. Mustafa Ch. Syntactic derivations of phrases in modern Uzbek and Turkish languages. Candidate of Philological Sciences dis. avtoref. - Tashkent, 2002.

16. Issues of development of Uzbek phrases in the XX century. Jabborov R. Mag.diss. Nukus:, 2014.

17. Vinogradov V.V. Questions of the study of the phrase, VYa. 1950 №3

18. Vinogradov V.V. Phrase study questions, VYa. 1954 P.106. 